\section{Decrease in the proportion of illicit cigarette use in Brazil: What does it really mean?}

\section{INTRODUCTION}

Brazil has continuous information on the proportion of smokers and legal cigarette production ${ }^{12}$; information is also available for a non-industry funded estimate of the size of illegal cigarette use from 2012 to $2016 .^{3}$

In the last years, the strategy of raising cigarette taxes has reduced smoking prevalence and legal cigarette consumption. However, because Brazil's neighbouring countries have lower taxes and prices, illicit trade has increased. ${ }^{34}$

We present an updated estimate of the proportion of illegal cigarette consumption for the year 2017 and discuss its implications for the full implementation of the tobacco price policy in Brazil and in other low-income and middle-income countries.

\section{METHODS}

In order to estimate the proportion and amount of illicit cigarette use in Brazil in 2017, we have combined available information on cigarette consumption from the VIGITEL 2017 phone survey ${ }^{1}$ and on official sales for domestic consumption provided by the Secretariat of Federal Revenues $^{2}$ for the same year, by using a constant estimate of the proportion of under-reporting of VIGITEL in relation to sales for domestic consumption in Brazil for a different baseline year (year 2013). The detailed approach has been published. $^{3}$

\section{RESULTS}

An increase in the size of the illicit market, and a decrease in both the consumption of legal cigarettes and the proportion of urban smokers, were observed between 2014 and 2016. From 2016 to 2017, however, the overall consumption of illicit cigarettes in Brazil decreased ( -4.8 billion units), the total yearly legal cigarette consumption increased slightly $(+2.7$ billion units), and the prevalence of smokers living in Brazilian state capitals remained virtually unchanged (-0.05\%) (figure 1).

\section{DISCUSSION}

By combining data on prevalence of smokers, sales production for domestic use and consumption of illegal cigarettes between 2016 and 2017, we found that the decline in the consumption of illegal cigarettes in Brazil was followed by an increase in the consumption of legal cigarettes.

Differently from what happened between 2014 and 2016, neither excise taxes on tobacco products nor the minimum cigarette price was increased in 2017, and Brazil experienced a temporary increase in the purchase power of the population. ${ }^{5}$ In addition, no substantial

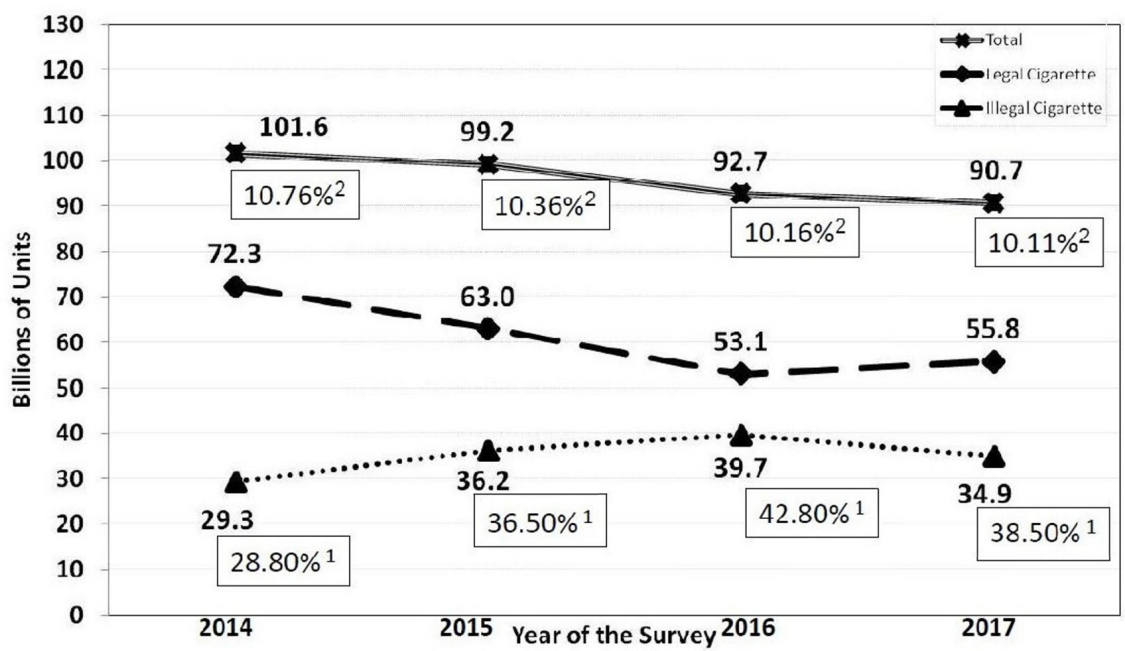

Notes: ${ }^{1}$ The proportion of illegal cigarettes consumed was estimated as the number of illegal cigarettes consumed divided by overall cigarettes consumed.$^{2}$ Information on smoking status from VIGITEL phone survey was used to estimate the proportion of smokers living in Brazilian state capitals

Figure 1 Amount of cigarettes (total, legal and illegal) consumed in Brazil from 2014 to 2017, proportion of illegal cigarettes consumed, ${ }^{1}$ and proportion of smokers living in Brazilian state capitals. $^{2}$

improvements in preventing non-duty paid cigarettes from Paraguay, a neighbouring country with much lower taxes and costs of production than Brazil, were observed between 2016 and 2017. Still, smokers who had previously been 'sensitised' by the increase in cigarette prices in past years (eg, individuals with low/ very low purchasing power), and who have migrated to cheaper illegal cigarettes, may be quitting smoking/reducing consumption now. ${ }^{1}$

Given that tobacco consumption poses a heavy burden on government and society, ${ }^{6}$ it is crucial to keep raising taxes on tobacco products and, at the same time, effectively promote the implementation of the Protocol to Eliminate Illicit Trade in Tobacco Products. ${ }^{7}$

Future research will be important in determining whether there is a reduction in both demand for and supply of tobacco.

Andre Salem Szklo, ${ }^{\oplus 1}$ Roberto Magno Iglesias ${ }^{2,3}$ ${ }^{1}$ Epidemiology, Brazilian National Cancer Institute, RIO DE JANEIRO, Brazil

${ }^{2}$ TCE/PND, World Health Organization, Geneva 27, Switzerland

${ }^{3}$ Center for Studies in Integration and Development (CINDES), Rio de Janeiro, Brazil

Correspondence to Mr Andre Salem Szklo; andreszk@hotmail.com

Acknowledgements We thank the NonCommunicable Diseases Surveillance and Health Promotion Department of the Health Surveillance Secretariat of the Ministry of Health (DANTPS/SVS/ MS) team working with the VIGITEL system for making available the database and for their general support.

Contributors ASS participated in data processing, data analysis and the elaboration and preparation of the article. RMI participated in the consultancy for data analysis and the elaboration and preparation of the article.

Funding The VIGITEL survey was funded by the Brazilian Ministry of Health.

Competing interests None declared.

Patient consent for publication Not required.

Provenance and peer review Not commissioned; externally peer reviewed.

(c) Author(s) (or their employer(s)) 2019. No commercial re-use. See rights and permissions. Published by BMJ.

\section{Check for updates}

To cite Szklo AS, Iglesias RM. Tob Control Epub ahead of print: [please include Day Month Year]. doi:10.1136/ tobaccocontrol-2018-054846

Received 16 November 2018

Revised 7 February 2019

Accepted 17 February 2019

Tob Control 2019:0:1-2.

doi:10.1136/tobaccocontrol-2018-054846 


\section{REFERENCES}

1 Brazilian Health Ministry. VIGITEL Brazil 2017: protective and risk factors for chronic diseases by telephone survey [in Portuguese]., 2018. Available: http://bvsms.saude. gov.br/bvs/publicacoes/vigitel_brasil_2017_vigilancia_ fatores_riscos.pdf [Accessed 28 Jan 2019].

2 Brazilian Ministry of Finance. Secretariat of federal revenue. Available: http://idg.receita.fazenda.gov.br/ orientacao/tributaria/regimes-e-controles-especiais [Accessed 28 Jan 2019].
3 Szklo A, Iglesias RM, Carvalho de Souza M, et al. Trends in illicit cigarette use in Brazil estimated from legal sales, 2012-2016. Am J Public Health 2018;108:265-9.

4 Iglesias RM, Szklo AS, Souza MCde, et al. Estimating the size of illicit tobacco consumption in Brazil: findings from the global adult tobacco survey. Tob Control 2017;26:53-9.

5 Ipeadata. Institute for Applied economic research. Available: http://www.ipeadata.gov.br/Default.aspx [Accessed 28 Jan 2019].
6 Pinto M, Bardach A, Palacios A. A. Carga de doença atribuível ao uso do tabaco no Brasil e potencial impacto do aumento de preços por meio de impostos. Documento técnico IECS N²1. Buenos Aires, Argentina: Instituto de Efectividad Clínica y Sanitaria, 2017.

7 World Health Organization. Protocol to eliminate illicit Trade in tobacco products, 2013. Available: http:// www.who.int/fctc/protocol/en/ [Accessed 28 Jan 2019]. 